\title{
Jenis Tanaman Obat di Kecamatan Semadam Kabupaten Aceh Tenggara
}

\author{
Muhammad Yassir ${ }^{1}$ \\ Meliyana ${ }^{2}$ \\ ${ }^{1,2}$ Pendidikan Biologi Universitas Gunung Leuser Aceh Tenggara \\ Email: Muhammadyassir404@gmail.com
}

\begin{abstract}
ABSTRAK
Tanaman obat tradisional masih terus dipakai oleh masyarakat walau dunia sudah modern. Tujuan dalam penelitian ini adalah untuk mengetahui jenis-jenis tanaman obat yang terdapat Kecamatan Semadam. Pengumpulan data dilaksanakan di desa Semadam Asal, desa Semadam Awal dan desa Suka Makmur Kecamatan Semadam Kabupaten Aceh Tenggara pada tanggal 18 sampai 30 September 2017. Metode yang digunakan dalam penelitian ini adalah metode survey dan observasi. Untuk menganalisis data dalam penelitian ini digunakan dalam bentuk grafik dan tabel. Ditemukan 346 individu tanaman obat dalam 21 Famili dan 29 jenis yang terbagi dalam 3 (tiga) lokasi penelitian.

Kata Kunci: Jenis tanaman obat
\end{abstract}

\section{PENDAHULUAN}

Indonesia adalah suatu negara kepulauan yang memiliki hutan tropika terbesar kedua di dunia, kaya dengan keanekaragaman hayati dan dikenal sebagai salah satu dari 7 negara "megabiodiversity" kedua setelah Brazilia (Ersam dalam dessy 2014). Indonesia diperkirakan memiliki hutan tropik mencapai 143 juta ha, merupakan tempat tumbuh $80 \%$ dari tanaman obat yang ada di dunia dimana 28.000 spesies tanaman tumbuhan dan 1.000 spesies diantaranya telah digunakan sebagai tanaman obat. Indonesia sangat kaya dengan berbagai jenis tumbuhan yaitu terdapat kurang lebih 30 ribu jenis yang sudah dikenal dari 40 ribu jenis tumbuhan yang ada di dunia. Sekitar $26 \%$ telah dibudidayakan dan sisanya sekitar $74 \%$ masih tumbuh liar di hutan (Fahrurozi dalam nurul tahun 2018). Rukmana dalam (Komang, 2017) mengatakan bahwa salah satu sumber daya kekayaan alam indonesia yang potensial merupakan tanaman obat, namun saat ini belum banyak dimanfaatkan. Tanaman obat merupakan bahan obat tradisional yang sudah sangat populer dikalangan masyarakat indonesia, terutama di pedesaan sejak zaman nenek moyang penggunaan obat tradisional sudah pernah dilakukan.

Aceh Tenggara merupakan daerah tropis dikarenakan dari aspek geografis kawasan Aceh Tenggara di kelilingi Taman Nasional Gunung Leuser dan terkenal kaya akan sumber daya hayati berupa jenis tumbuh-tumbuhan beranekaragam, salah satunya adalah jenis tanaman obat. Tumbuhan obat adalah tanaman yang salah satu atau seluruh bagian pada tumbuhan tersebut mengandung zat aktif yang berkhasiat bagi kesehatan yang dapat dimanfaatkan sebagai penyembuh penyakit seperti tumor, kanker, 6 
menghambat pertumbuhan sel-sel yang tidak normal. Tumbuhan obat merupakan tumbuhan berkhasiat obat yang dapat membunuh bibit penyakit, menghilangkan rasa sakit, meningkatkan daya tahan tubuh dan memperbaiki organ yang rusak. Kecamatan semadam mendapatkan tanaman obat dengan cara mencarinya di pekarangan rumah atau hutan berupa tanaman liar atau membeli di pasar. Bagian tumbuhan obat dimaksud adalah daun, buah, bunga, akar, rimpang, batang (kulit), dan getah (resin). Bagian tumbuhan yang paling banyak digunakan adalah daun dengan persentase sebesar $57,97 \%$, sedangkan yang paling sedikit digunakan adalah bagian bunga, dengan persentase sebesar $1,44 \%$. Hal ini disebabkan karena mudah didapatkan dan pada daun terakumulasi senyawa metabolit sekunder yang berguna sebagai obat, seperti flavonoid (John 2008).

Pada umumnya, Tanaman obat sangat sering digunakan sebagai bahan baku obat tradisional dan jamu, yang jika digunakan akan meningkatkan sistem kekebalan tubuh (immune system), karena tanaman ini mempunyai sifat spesifik sebagai tanaman obat yang bersifat pencegahan (preventif) dan promotif melalui kandungan metabolit sekunder pada jahe seperti gingiro dan pada temulawak santoriso yang mampu meningkatkan sistem kekebalan tubuh Salah satu jenis tanaman obat yang paling popular digunakan sebagai bahan baku utama jamu dan obat tradisional adalah jahe. (BPS, 2016 dalam salim 2017 ). Penggunaan obat tradisional sudah membudaya di kecamatan semadam selain melakukan pengobatan modern, masyarakat juga melakukan pengobatan alternatif menggunakan beberapa tanaman obat tradisional untuk mengatasi dan mengobati berbagai macam jenis penyakit, seperti diare, diabetes dan lain-lain. Hal ini dipengaruhi oleh melonjaknya harga obat sintetik sehingga masyarakat kembali memanfaatkan tanaman obat. Manfaat penggunaan tanaman obat sangat besar, seperti dalam keadaan ekonomi masyarakat, dengan adanya penggunaan obat tradisional ini akan menghemat biaya kehidupan karena pengobatan tradisional selain bahannya dapat diperoleh dengan mudah di alam, pengobatan ini lebih murah, aman dan tidak memiliki efek samping yang besar. Departemen kesehatan melalui Undang-undang No. 1076 tahun 2003 tentang penyelenggaraan pengobatan tradisional mengakui keberadaan pengobatan tradisional dan obat tradisional sebagai bagian yang tidak dapat diabaikan dalam pelayanan kesehatan. Obat tradisional merupakan warisan turun-temurun dari nenek moyang yang berakar kuat dalam budaya bangsa, oleh karena itu baik dalam ramuan maupun dalam penggunaannya sebagai obat tradisional masih berdasarkan pengalaman yang diturunkan dari generasi ke generasi baik secara lisan maupun tulisan ( Riswan dalam, Siti Aminah 2016).

Penelitian mengenai jenis-jenis tanaman obat di kecamatan semadam mungkin sudah pernah dilakukan pada tahun sebelumnya, oleh sebab itu perlu dilakukan penelitian ulang tentang jenis-jenis tanaman obat sebagai data di kecamatan semadam untuk saat ini. Hasil penelitian ini nantinya diharapkan dapat menambah pengetahuan tentang jenis-jenis tanaman obat sehingga dapat dijadikan sebagai media pembelajaran botani tumbuhan tinggi, dimana tanaman obat selain dapat dipelajari secara materi, ternyata praktik lapangan mengenal berbagai jenis tanaman obat secara langsung jelas diperlukan. 
Muhammad Yassir, dan Meliyana

\section{METODE}

Penelitian ini dilaksanakan di desa Semadam Asal, desa Semadam Awal dan desa Suka Makmur Kecamatan Semadam Kabupaten Aceh Tenggara pada tanggal 18 sampai dengan 30 September 2017. Objek penelitian adalah jenis tanaman obat yang ditemukan pada saat melakukan penelitian di desa Semadam Asal, desa Semadam Awal dan desa Suka Makmur.

Metode yang digunakan dalam penelitian ini adalah metode survey dan observasi. Metode survey digunakan untuk menentukan lokasi penelitian, sedangkan metode observasi digunakan untuk mengamati jenis tanaman obat pada saat melakukan penelitian. Berdasarkan hasil survey lokasi pengamatan dibagi menjadi 3 (tiga) stasiun yaitu stasiun 1 (satu) di desa semadam asal, stasiun 2 (dua) di desa semadam awal dan stasiun 3 (tiga) di desa suka makmur. Masing-masing stasiun menggunakan lokasi dengan luas $500^{2}$ (20 m x $\left.25 \mathrm{~m}\right)$. Pengamatan jenis tanaman obat dilihat berdasarkan teknik Purposive Sampling. Setelah tanaman obat ditemukan, maka terlebih dahulu dilakukan pemotretan, kemudian dicatat karakteristik morfologi tanaman obat. Parameter yang dicatat digunakan untuk keperluan identifikasi jenis tanaman obat meliputi ciri-ciri morfologi jenis tanaman obat yang ditemukan.

\section{HASIL DAN PEMBAHASAN}

Berdasarkan hasil penelitian yang telah dilaksanakan di Kecamatan Semadam Kabupaten Aceh Tenggara pada pada tanggal 18 sampai 30 September 2017 di 3 (tiga) lokasi pengambilan sampel yaitu desa Semadam Asal, Semadam Awal dan desa Suka Makmur, ditemukan tanaman obat yang dalam 21 famili. Famili yang diperoleh yaitu Lauraceae, Oxalidaceae, Cactaceae, Liliaceae, Amaranthaceae, Zingiberaceae, Solanaceae, Myrtaceae, Piperaceae, Arecaceae, Euphorbiaceae, Rutaceae, Fabaceae, Thymelacaceae, Rubiaceae, Apocynaceae, Pandanaceae, Palmae, Caricaceae, Poaceae, dan Annonaceae. Sedangkan jumlah keseluruhan adalah 346 individu.

Dari ke 29 jenis tanaman obat yang paling dominan yaitu tergolong pada famili Zingiberaceae dengan jumlah 6 jenis (Zingiber purpureum, Zingiber officinale, Curcuma domestica, Kaempferia galanga, Languas galanga dan Curcuma xanthorrhiza) ditemui dari keseluruhan lokasi pengamatan dengan jumlah terbesar dibanding dengan tanaman obat dari famili yang lainnya. Jenis tumbuhan famili Zingiberaceae paling banyak dimanfaatkan sebagai komponen utama dalam bahan baku obat tradisional yaitu tumbuhan rimpang- rimpangan. Dalam rimpang tanaman Zingiberacea mengandung minyak atsiri dan alkaloid yang berkhasiat sebagai obat (Wasikhah, 2016). Zingiber officinale juga bisa digunakan sebagai obat radang tenggorokan (Aflinda, 2015). Adapun komposisi jenis tanaman obat yang ditemukan dapat dilihat pada Tabel 1.

Tabel. 1. Jenis jenis Tanaman Obat yang ditemukan di Lokasi Penelitian 
Serambi Saintia

Jurnal Sains dan Aplikasi
Volume VII, No.1, April 2019

pISSN $2337-9952$

eISSN $2656-8446$

\begin{tabular}{|c|c|c|c|c|c|c|c|}
\hline \multirow[t]{2}{*}{ No } & \multirow[t]{2}{*}{ Nama Jenis } & \multirow[t]{2}{*}{ Nama Ilmiah } & \multirow[t]{2}{*}{ Famili } & \multicolumn{3}{|c|}{ Kecamatan } & \multirow[t]{2}{*}{$\mathrm{Jlh}$} \\
\hline & & & & Asal & Awal & SM & \\
\hline 1 & Alpukat & Persea americana & Lauraceae & 2 & - & 1 & 3 \\
\hline 2 & $\begin{array}{l}\text { Belimbing } \\
\text { Wuluh }\end{array}$ & Averrhoa bilimbi & Oxalidaceae & 2 & 1 & 1 & 4 \\
\hline 3 & Buah Naga & $\begin{array}{l}\text { Hylocereus } \\
\text { undatus }\end{array}$ & Cactaceae & - & - & 2 & 2 \\
\hline 4 & Bayam Duri & $\begin{array}{l}\text { Amaranthus } \\
\text { spinoususu }\end{array}$ & Amaranthaceae & 2 & 1 & 2 & 5 \\
\hline 5 & Bengle & $\begin{array}{l}\text { Zingiber } \\
\text { purpureum }\end{array}$ & Zingiberaceae & 6 & 4 & 2 & 12 \\
\hline 6 & Cabe Merah & $\begin{array}{l}\text { Capsicum } \\
\text { апnиит }\end{array}$ & Solanaceae & 2 & 3 & 2 & 7 \\
\hline 7 & Daun Salam & $\begin{array}{l}\text { Syzygium } \\
\text { polyanthum }\end{array}$ & Myrtaceae & 1 & - & 1 & 2 \\
\hline 8 & Daun Sirih & Piper betle & Piperaceae & 4 & 2 & 2 & 8 \\
\hline 9 & Deringo & $\begin{array}{l}\text { Acorus } \\
\text { calamus }\end{array}$ & Arecaceae & 2 & 3 & - & 5 \\
\hline 10 & Jahe & $\begin{array}{l}\text { Zingiber } \\
\text { officinale }\end{array}$ & Zingiberaceae & 12 & 6 & 8 & 26 \\
\hline 11 & Jarak Pagar & $\begin{array}{l}\text { Jatropha } \\
\text { curcas }\end{array}$ & Euphorbiaceae & 5 & 6 & 4 & 15 \\
\hline 12 & Jambu Biji & $\begin{array}{l}\text { Psidium } \\
\text { guajava }\end{array}$ & Myrtaceae & 2 & 1 & 1 & 4 \\
\hline 13 & Jeruk Nipis & $\begin{array}{l}\text { Citrus } \\
\text { aurantifolia }\end{array}$ & Rutaceae & 3 & 1 & 1 & 5 \\
\hline 14 & Kunyit & $\begin{array}{l}\text { Curcuma } \\
\text { domestica }\end{array}$ & Zingiberaceae & 17 & 24 & 8 & 49 \\
\hline 15 & Kencur & $\begin{array}{l}\text { Kaempferia } \\
\text { galanga }\end{array}$ & Zingiberaceae & 6 & 4 & 3 & 13 \\
\hline 16 & Ketepeng & Cassia alata & Fabaceae & 2 & - & 1 & 3 \\
\hline 17 & Lada Hitam & Piper nigrum & Myrtaceae & - & 1 & - & 1 \\
\hline 18 & Lengkuas & $\begin{array}{l}\text { Languas } \\
\text { galanga }\end{array}$ & Zingiberaceae & 16 & 12 & 8 & 36 \\
\hline 19 & Lidah Buaya & Aloe vera & Liliaceae & 3 & 2 & - & 5 \\
\hline 20 & Mahkota Dewa & $\begin{array}{l}\text { Phaleria } \\
\text { macrocarpa }\end{array}$ & Thymelacaceae & 2 & 1 & 1 & 4 \\
\hline 21 & Mengkudu & $\begin{array}{l}\text { Moridnda } \\
\text { citrifolia }\end{array}$ & Rubiaceae & 1 & 1 & - & 2 \\
\hline 22 & Meniran & $\begin{array}{l}\text { Phyllanthus } \\
\text { niruri }\end{array}$ & Euphorbiaceae & 3 & 5 & 3 & 11 \\
\hline 23 & Tapak Dara & $\begin{array}{l}\text { Catharanthus } \\
\text { roseus }\end{array}$ & Apocynaceae & 4 & 6 & 7 & 17 \\
\hline
\end{tabular}


Muhammad Yassir, dan Meliyana

\begin{tabular}{|c|l|l|l|r|r|r|c|}
\hline 24 & Pandan Wangi & $\begin{array}{l}\text { Pandanus } \\
\text { amaryllyfolius }\end{array}$ & Pandanaceae & 12 & 8 & 14 & 34 \\
\hline 25 & Pinang & Areca catechu & Palmae & 4 & 2 & 4 & 10 \\
\hline 26 & Pepaya & Carica papaya & Caricaceae & 5 & 2 & 4 & 11 \\
\hline 27 & Sereh & $\begin{array}{l}\text { Cymbopogon } \\
\text { nardus }\end{array}$ & Poaceae & 14 & 10 & 8 & 32 \\
\hline 28 & Temulawak & $\begin{array}{l}\text { Curcuma } \\
\text { xanthorrhiza }\end{array}$ & Zingiberaceae & 8 & 6 & 2 & 16 \\
\hline 29 & Sirsak & $\begin{array}{l}\text { Annona } \\
\text { muricata }\end{array}$ & Annonaceae & 2 & 1 & 1 & 4 \\
\hline 30 & Jumlah & & 142 & 113 & 91 & 346 \\
\hline
\end{tabular}

Berdasarkan tabel di atas pada jenis Persea americana ditemukan 3 individu di 2 lokasi penelitian. Pada jenis Averrhoa bilimbi ditemukan 4 individu di 3 lokasi penelitian. Sedangkan jenis Hylocereus undatus ditemukan 2 individu tapi hanya pada 1 lokasi penelitian. Pada jenis Amaranthus spinoususu ditemukan 5 individu di 3 lokasi penelitian. Pada jenis Zingiber purpureum ditemukan 12 individu di 3 lokasi penelitian. Selanjunya jenis Capsicum annuum ditemukan 7 individu pada 3 lokasi penelitian. Pada jenis Syzygium polyanthum ditemukan 2 individu di 2 lokasi penelitian. Sedangkan jenis Piper betle ditemukan 8 individu di 3 lokasi penelitian. Selanjutnua jenis Acorus calamus ditemukan 5 individu tapi hanya pada 2 lokasi penelitian.

Pada jenis Zingiber officinale ditemukan 26 individu di 3 lokasi penelitian. Selanjutnya jenis Jatropha curcas ditemukan 15 individu di 3 lokasi penelitian. Sedangkan pada jenis Psidium guajava ditemukan 4 individu di 3 lokasi penelitian. Pada jenis Citrus aurantifolia ditemukan 5 individu pada 3 lokasi penelitian. Selanjutnya pada jenis Curcuma domestica ditemukan 49 individu juga di 3 lokasi penelitian. Kemudian jenis Kaempferia galanga ditemukan 13 individu di 3 lokasi penelitian. Pada jenis Cassia alata ditemukan 3 individu di 2 lokasi penelitian. Sedangkan pada jenis Piper nigrum ditemukan 1 individu di 1 lokasi penelitian.

Pada jenis Languas galanga ditemukan 36 individu di 3 lokasi penelitian. Selanjunya jenis Aloe vera ditemukan 5 individu tapi hanya pada 2 lokasi penelitian. Pada jenis Phaleria macrocarpa ditemukan 4 individu di 3 lokasi penelitian. Sedangkan jenis Morinda citrifolia ditemukan 2 individu di 2 lokasi penelitian. Selanjutnua jenis Phyllanthus niruri ditemukan 11 individu pada 3 lokasi penelitian. Pada jenis Catharanthus roseus ditemukan 17 individu di 3 lokasi penelitian. Selanjutnya jenis Pandanus amaryllyfolius ditemukan 34 individu di 3 lokasi penelitian. Sedangkan pada jenis Areca catechu ditemukan 10 individu di 3 lokasi penelitian. Pada jenis Carica papaya ditemukan 11 individu pada 3 lokasi penelitian. Selanjutnya pada jenis Cymbopogon nardus ditemukan 32 individu juga di 3 lokasi penelitian. Kemudian jenis Curcuma xanthorrhiza ditemukan 16 individu di 3 lokasi penelitian. Pada jenis Annona muricata ditemukan 4 individu juga di 3 lokasi penelitian. Daun sirsak (Annona muricata) mengandung suatu zat yaitu annonaceus acetogenins yang dapat membunuh sel kanker (Zuhud, 2011, dalam Andalia, 2018). 
Perbandingan jenis tanaman obat yang ditemukan di Kecamatan Semadam Kabupaten Aceh Tenggara Tahun 2017 pada setiap lokasi penelitian dapat dilihat pada gambar di bawah ini.

\section{Gambar : Diagram perbandingan jenis tanaman obat berdasarkan lokasi yang ditemukan di Kecamatan Semadam}

Berdasarkan diagram di atas dapat dilihat bahwa pada lokasi I desa Semadam Asal ditemukan 142 individu tanaman obat. Jenis yang paling banyak ditemukan pada lokasi ini adalah Curcuma domestica sebanyak 17 individu. Pada lokasi II desa Semadal Awal ditemukan 113 individu tanaman obat. Jenis yang paling banyak ditemukan pada lokasi ini adalah Curcuma domestica sebanyak 24 individu. Pada lokasi III desa Suka Makmur ditemukan 91 individu tanaman obat. Jenis yang paling banyak ditemukan pada lokasi ini adalah Pandanus amaryllyfolius sebanyak 14 individu.

\section{PENUTUP}

Ditemukan 346 individu tanaman obat dalam 21 Famili (Lauraceae, Oxalidaceae, Cactaceae, Liliaceae, Amaranthaceae, Zingiberaceae, Solanaceae, Myrtaceae, Piperaceae, Arecaceae, Euphorbiaceae, Rutaceae, Fabaceae, Thymelacaceae, Rubiaceae, Apocynaceae, Pandanaceae, Palmae, Caricaceae, Poaceae, dan Annonaceae) dan 29 jenis yang terbagi dalam 3 (tiga) lokasi penelitian.

\section{DAFTAR RUJUKAN}

Abdi, S.K. dkk. 2017. Jenis dan Pemanfaatan Tanaman Obat Di Desa Tinading dan Pengembangannya sebagai Media Pembelajaran. Jurnal Jip Biol 5 (2): 6070.

Andalia, N. dkk. 2018. Persepsi Masyarakat Gampong Lampaya Lhoknga terhadap Tanaman Sirsak sebagai Pencegah Kanker. 
Muhammad Yassir, dan Meliyana

http://www.ojs.serambimekkah.ac.id/index.php/serambisaintia/article/view/597/545

John, A, O. dkk, 2008. Antidiarrhoeal Activity of Psidium Guajava L. Linn. (Myrtaceae) Leaf Aqueous Extract In Rodents. Journal Smooth Muscle Res. 44 (6): 195-207.

Nur Aflinda, dan Armi, 2015. Identifikasi Jenis Tumbuhan Tradisional yang digunakan sebagai Obat Radang Tenggorokan di Desa Reuhat Tuha Kecamatan Suka Makmur Aceh Besar. http://www.ojs.serambimekkah.ac.id/index.php/serambiakademika/article/view/67/66

Qamariah, N. Dkk. 2018. Inventarisasi Tumbuhan Obat di Desa Pelangsian Kecamatan Mentawa Baru Ketapang Kabupaten Kotawaringin Timur. Journal Of Pharmacy. 1 (1): 1-10.

Salim. 2017. Info Komuniti Tanaman Obat. Badan Pengkajian dan engembangan Kementerian Perdagangan Republik Indonesia: Jakarta.

Siti, A. dkk. 2016. Tumbuhan Obat yang Dimanfaatkan oleh Battra di Desa Sejahtera Kecamatan Sukadana Kabupaten Kayong Utara. Jurnal hutan lestari 4 (3) : 299 305.

Wasikhah, 2016. Tumbuhan Zingiberaceae sebagai obat obat obatan.

http://www.ojs.serambimekkah.ac.id/index.php/serambi-saintia/article/view/114 